\title{
Mercury concentration in lichen, moss and soil samples collected from the forest areas of Praded and Glacensis Euroregions (Poland and Czech Republic)
}

\author{
Andrzej Kłos • Malgorzata Rajfur • Ivo Šrámek • \\ Maria Waclawek
}

Received: 28 April 2011 / Accepted: 15 November 2011 /Published online: 2 December 2011

(C) The Author(s) 2011. This article is published with open access at Springerlink.com

\begin{abstract}
The concentration of mercury was determined in samples of the lichen Hypogymnia physodes, the moss Pleurozium schreberi, and the soil humus collected in Polish and Czech Euroregions Praded and Glacensis. The sampling sites were located in Bory Stobrawskie, Bory Niemodlińskie and Kotlina Kłodzka in Poland, and in Jeseniki and Gory Orlickie in the Czech Republic. The mean concentrations of mercury accumulated in the lichen $\left(0.129 \mathrm{mg} \mathrm{g}^{-1}\right)$, in the moss $\left(0.094 \mathrm{mg} \mathrm{g}^{-1}\right)$ and in soil $\left(0.286 \mathrm{mg} \mathrm{g}^{-1}\right)$ were fairly close to the corresponding concentrations in other low-industrialized regions. The highest concentrations of mercury were observed in the lichen and the moss samples from Kotlina Kłodzka. The primary deposition of mercury was evaluated using the comparison factor, defined as the ratio of a difference between the concentrations of a bioavailable analyte in lichens and in mosses, to the arithmetic mean of these concentrations.
\end{abstract}

A. Kłos $(\bowtie) \cdot$ M. Rajfur $\cdot$ M. Wacławek

Chair of Biotechnology and Molecular Biology,

University of Opole,

4 kard. B. Kominka Str.,

45-032 Opole, Poland

e-mail: aklos@uni.opole.pl

I. Šrámek

Health Institute in Hradec Králové (ZÚHK),

Habrmanova 154,

501-01 Hradec Králové, Czech Republic
Keywords Mercury · Anthroposphere - Environmental pollution · Biomonitoring $\cdot$ Comparison factor

\section{Introduction}

The influence of the anthroposphere on the environment has been observed for a long time. The biosphere has a self-cleaning ability to accommodate and destroy some limited amounts of pollutants. Breaking the limits of pollution usually results in ecological disasters and irreversible changes in ecosystems. Among many toxins released to the environment due to human activities, mercury is particularly important. It moves easily between the air, water and soil matrices because it has low melting temperature $(234.32 \mathrm{~K})$, high volatility and an ability of biotransformation (methylation, alkylation and reduction). Due to the mercury reduction by microorganisms (Głuszcz et al. 2008), evaporation and phyto-volatilization (Che et al. 2003), mercury translocates from soil to air. Long-range transport of airborne mercury vapour made the mercury pollution a global problem. That was confirmed by the observation of increasing concentration of mercury in polar regions (Travnikov 2005).

Mercury is traded freely on the world market, with a current global supply close to 3,600 tonnes per year (Overarching Framework UNEP Global Mercury Partnership 2009). It is released to the atmosphere mainly from the combustion of coal and lignite, and 
from the production of cement. The less significant sources of mercury include the production of iron and steel and the combustion of wastes, as well as the mining of gold by the amalgam method, and the mercury process of chlorine production, both currently avoided. Mercury is also used in dentistry and in making of light bulbs and batteries. Main natural sources of mercury pollution include volcanic eruptions, erosion of mercury-containing minerals and geothermal processes (Loppi et al. 2006).

In January 2005, the European Commission presented a strategy for mercury, which had been supported both by the Council of Ministers and by the European Parliament. The strategy has important objectives: the reduction of mercury emissions, the reduction of mercury input into the circulation within society by cutting the supply and the demand, resolving the long-term fate of mercury surpluses and societal reservoirs, the protection against mercury exposure, the improved understanding of the mercury problem and its solutions, and supporting and promoting the international actions on mercury (Commission of the European Communities 2005). In December 2008, the Commission of the European Communities issued a Recommendation for the European Council on the participation of the European Community in the negotiations towards a legally binding instrument on mercury further to Decision 24/ 3 of the Governing Council of the UNEP.

Following the EU Directives, Poland and Czech Republic began to inventory and reduce the emission of mercury. Data from the European Monitoring Environmental Program (EMEP) show that in 1990, the total mercury emission in Poland and in Czech Republic reached 33 and $7.5 \mathrm{Mg}_{\text {year }}{ }^{-1}$, respectively. In 2008, these values dropped severally to 16 and 4.1 Mg year ${ }^{-1}$ (EMEP 2010). The main source of atmospheric emission of mercury in Poland is combustion of lignite and hard coal (Pacyna et al. 2006; Głodek and Pacyna 2009). The Czech mercury emissions were not inventoried until the present, but similar to Poland, combustion of lignite and fossil fuels is expected to be the major source.

For many years, the technical monitoring of the environmental pollution has been supported with the biomonitoring studies that examined the content of many trace elements in various components of the biota (Wolterbeek 2003; Markert et al. 2003; Smodiš et al. 2004; Markert 2007). The biomonitoring helps to assess the pollution of considered regions, to locate the sources of pollutants and to estimate the transport vectors of pollutants. It provides useful information on time changes of the amounts of elements accumulated in the biological material (Bennett and Wetmore 1997) and on the distribution of pollutants across the consecutive levels of the trophic chains in various ecosystems (Kehrig et al. 2010; Dang and Wang 2010). The contamination of atmospheric aerosols is often resolved with the use of mosses and lichens (Fraenzle and Markert 2007; Markert et al. 2008). Lichens are less tolerant to pollutants, so they are used mostly for the non-methodical or local studies. The concentration of mercury in lichen samples collected in various regions of the world ranged: from 0.03 to $1.18 \mathrm{\mu g} \mathrm{g}^{-1}$ in a geothermal area of Mt. Amiata in Central Italy (Loppi et al. 2006); from 0.06 to $1.38 \mu \mathrm{g} \mathrm{g}^{-1}$ in the Nahuel Huapi National Park in Patagonia, Argentina (Ribeiro Guevara et al. 2004); from 0.28 to $3.66 \mu \mathrm{g} \mathrm{g}^{-1}$ near a chloralkali plant in New Brunswick, Canada (Sensen and Richardson 2002); from 0.006 to $0.234 \mu \mathrm{g} \mathrm{g}^{-1}$ in South-Eastern Louisiana (Becnel et al. 2004); from 0.045 to $0.660 \mu \mathrm{g} \mathrm{g}^{-1}$ in the Kejimkujik National Park in Nova Scotia, Canada (Rencz et al. 2003); from 0.07 to $0.29 \mathrm{\mu g} \mathrm{g}^{-1}$ in the Yellowstone National Park in the USA (Bennett and Wetmore 1999) and from 0.08 to $2.06 \mu \mathrm{g} \mathrm{g}^{-1}$ on the shores of the Hudson Bay in Canada (Carignan and Sonke 2010).

Every 5 years since 1990, the European countries carry out methodical studies of heavy metals accumulated in mosses, which include mercury. The studies are part of The International Cooperative Programme on Effects of Air Pollution on Natural Vegetation and Crops (ICP Vegetation), which was established in 1987 under the United Nation Economic Commission for Europe Convention on LongRange Transboundary Air Pollution (Harmens et al. 2009). The program is coordinated by the ICP Vegetation Coordination Centre affiliated with the Centre for Ecology and Hydrology in Bangor, UK. In 2005, it gathered 28 countries, including Poland and Czech Republic. The median concentrations of mercury in mosses determined in these countries ranged from $0.012 \mu \mathrm{g} \mathrm{g}^{-1}$ in Spain to $0.14 \mu \mathrm{g} \mathrm{g}^{-1}$ in Belgium (Harmens et al. 2010a). In Czech Republic, the concentration was $0.045 \mu \mathrm{g} \mathrm{g}^{-1}$, while in Poland it was not determined. A similar study was carried out in 2000 by the Visegrád Group countries 
(Hungary, Czech Republic, Poland and Slovakia). The determined median concentrations of mercury in mosses ranged from 0.06 to $0.32 \mu \mathrm{g} \mathrm{g}^{-1}$ in Slovakia and from 0.020 to $0.105 \mu \mathrm{g} \mathrm{g}^{-1}$ in Czech Republic (Suchara et al. 2007). Another study was carried out in 2007 near the Spolana works in Neratovice, Czech Republic, which manufacture chlorine using the mercury technology. The measured concentrations of mercury in mosses depended on the distance of the sampling sites from the works, and ranged from $0.85 \mu \mathrm{g} \mathrm{g}^{-1}$ maximum at distances shorter than $0.5 \mathrm{~km}$ to $0.09 \mu \mathrm{g} \mathrm{g}^{-1}$ minimum at $10 \mathrm{~km}$ (Suchara and Sucharova 2008). Attempts to correlate the deposition models, such as those used in EMEP, with the concentrations of mercury determined in mosses were unsatisfactory (Harmens et al. 2010b). Studies carried out in Norway indicated that mosses absorb well not only the $\mathrm{Hg}^{2+}$ ions, but also the airborne elemental mercury $\mathrm{Hg}^{0}$ (Steinnes et al. 2003). Probably, sorption of mercury by lichens and mosses is influenced by climate conditions as well as by dry and wet deposition. The comparison of results obtained from projects carried out in European countries in 1995 and 2005 showed that in spite of many discrepancies, these projects significantly contributed to the evaluation of time trends of the environmental pollution and were consistent with the EMEP studies (Harmens et al. 2010a, b).

Soil is also a matrix used for the assessment of mercury pollution. Studies carried out in Poland and Czech Republic measured the concentrations of mercury which ranged from 0.47 to $4.67 \mu \mathrm{g} \mathrm{g}^{-1}$ near the aforementioned Spolana works (Suchara and Sucharova 2008); $1.490 \mu \mathrm{g} \mathrm{g}^{-1}$ mean in forest soils and $0.289 \mu \mathrm{g} \mathrm{g}^{-1}$ mean in arable soils near a lead smelter in Prríbram, Czech Republic (Ettler et al. 2007); $0.633 \mu \mathrm{g} \mathrm{g}^{-1}$ maximum in the soil humus in the Bohemian Switzerland National Park, Czech Republic (Navrátil et al. 2009); from 62 to $393 \mu \mathrm{g} \mathrm{g}^{-1}$ in dry soil matter in Warsaw, Poland, near a plant manufacturing thermometers, areometers and electrical switches containing mercury (Boszke et al. 2008); from 0.146 to $0.193 \mu \mathrm{g} \mathrm{g}^{-1}$ in soil humus from the Holy Cross Mountains in Poland (Migaszewski et al. 2002) and $0.080 \mu \mathrm{g} \mathrm{g}^{-1}$ mean in the Wigry National Park, Poland (Migaszewski et al. 2005).

Our study was aimed at the assessment of mercury pollution in the Praded and Glacensis Euroregions, including identification of plausible sources of mercury involved. Mercury was determined in samples of an epiphytic lichen, an epigeal moss and a surface layer of soil humus. The presented research was part of the Operational Programme for Transboundary Cooperation between Czech Republic and Poland, entitled "Biomonitoring research in PolishCzech transboundary region".

\section{Materials and methods}

The research was carried out in the forested areas of the Praded and Glacensis Euroregions - Bory Stobrawskie (BS), Bory Niemodlińskie (BN) and Kotlina Kłodzka (KK) in Poland, and Jeseniki $(\mathrm{J})$ in the Czech Republic. The selected areas had similar tree cover (pine and spruce forests) but differed in the soil texture. In Bory Niemodlińskie and Bory Stobrawskie, the sand was covered with soil layer at least $3 \mathrm{~cm}$ thick. The geologically inhomogeneous soils in Kotlina Kłodzka and Jeseniki, typical for the Sudety Mountain range, included mountain soils (acid brown and leached brown), upland soils (podzolic and brown), valley soils (alluvial, mursh and gley) and initial soils. Samples of the epiphytic lichen Hypogymnia physodes, the epigeal moss Pleurozium schreberi and soil (ectohumus) were collected from April to September 2010.

Figure 1 shows the map with localization of sampling sites. On 41 sites, samples of lichens, mosses and soil were collected while on 14 sites lichens were not found, so only moss and soil samples were taken.

\section{Collection and preparation of samples}

At each sampling site (Fig. 1), six samples of each material (the lichen, the moss and soil) were collected from six different points and mixed together. Each sampling site was about $30 \mathrm{~m}^{2}$ large. The lichen was collected from horizontally growing branches of spruce or larch trees, at $1.5-2 \mathrm{~m}$ above the ground. In the vicinity of each sampled tree, samples of green parts of mosses and of organic layer of soil were collected, the latter at the depth not bigger than $5 \mathrm{~cm}$. The personnel used rubber gloves and put each sample in a paper bag. The sampling sites, which were chosen randomly, uniformly cover the studied areas. All sites were flat places covered with a 
Fig. 1 Map with localization of sampling sites

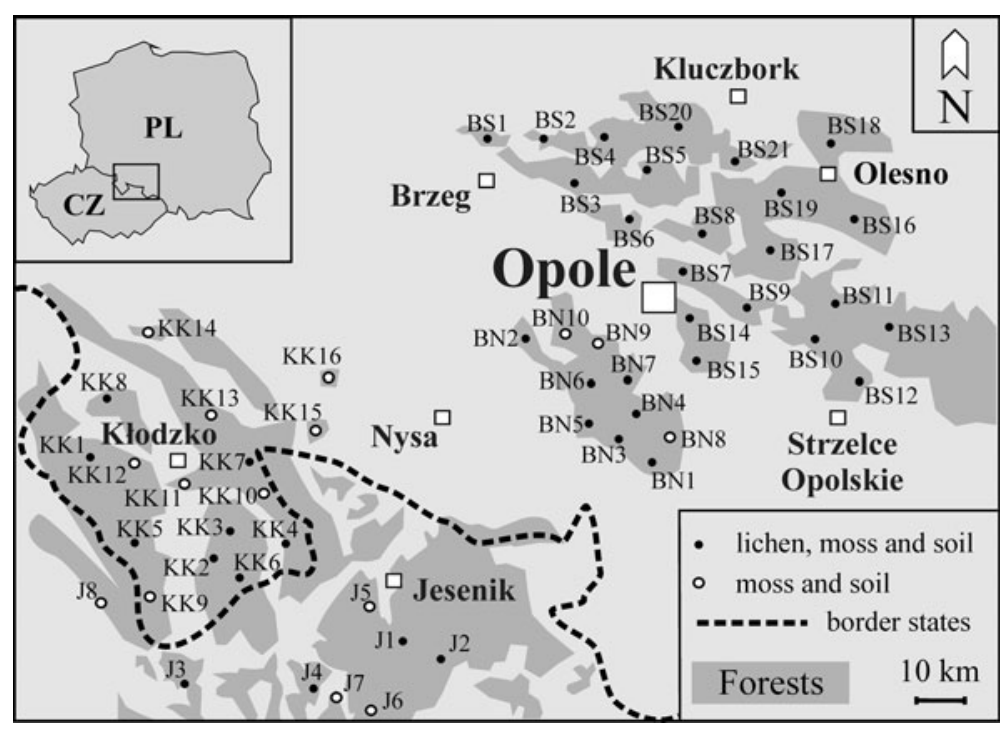

coniferous forest and were located at least $100 \mathrm{~m}$ away from roads and buildings. They hosted mosses and, if possible, lichens - only at 14 of 55 sites, the lichen $H$. physodes did not occur. Total amounts of materials collected at each sampling site were: $20 \mathrm{~g}$ of the lichen, $20 \mathrm{~g}$ of the moss and $500 \mathrm{~g}$ of soil. The lichen and the moss samples were cleaned of mechanical impurities and dried at temperatures not higher than $373 \mathrm{~K}$. Soil samples were sifted with a sieve of $2 \mathrm{~mm}$ mesh size and dried at $273 \mathrm{~K}$. Then, the samples were homogenized in agate mortars and sifted again with a sieve of $0.4 \mathrm{~mm}$ mesh size. The amounts of materials taken for the analyses were: $0.03-0.04 \mathrm{~g}$ of the lichen or the moss, and 0.09$0.10 \mathrm{~g}$ of the soil. Preparation of samples followed the standard operating procedure (SOP) HK 200.03 developed according to the Czech standard ČSN 757440.

\section{Analysis}

The analyses were carried out in the accredited laboratories of the Health Institute in Hradec Králové (ZÚHK) and the Chair of Biotechnology and Molecular Biology, University of Opole (UO). The concentration of mercury in the samples was determined with AMA 254 mercury analyzers from Altec Ltd., CZ. The AMA 254 is a single-band atomic absorption spectrometer with a serial system of two measurement cuvettes, and a low-pressure mercury lamp with peak emission at $253.65 \mathrm{~nm}$. It has a detection limit of $0.003 \mathrm{ng} \mathrm{Hg}$ and a quantification limit of $0.01 \mathrm{ng} \mathrm{Hg}$.

Quality assessment/quality control

The quality control of measurements was assured by test analyses of the BCR-482 lichen reference material from the Institute for Reference Materials and Measurements in Belgium. The obtained results are summarized in Table 1.

In addition, the interlaboratory analyses of selected samples were carried out in ZÚHK and in UO. The samples of the lichen, the moss and soil were collected in BS at sites 11, 13, 14, 16 and 19-21. The maximal standard deviations of the mean, characterizing the obtained results, were: $7.9 \%$ for the lichen, $9.2 \%$ for the moss and $8.8 \%$ for the soil.

Table 1 Measured and certified values of $\mathrm{Hg}$ concentration in the BCR 482 lichen reference material

\begin{tabular}{|c|c|c|c|c|c|c|c|}
\hline \multicolumn{2}{|l|}{ BCR-482 lichen } & \multicolumn{3}{|l|}{ AMA (UO) } & \multicolumn{3}{|c|}{ AMA (ZÚHK) } \\
\hline Certified value $(\mu \mathrm{g} / \mathrm{g})$ & \pm Uncertainty $(\mu \mathrm{g} / \mathrm{g})$ & Mean $(\mu \mathrm{g} / \mathrm{g})$ & $\pm \mathrm{SD}(\mu \mathrm{g} / \mathrm{g})$ & $D^{\mathrm{a}}(\%)$ & Mean $(\mu \mathrm{g} / \mathrm{g})$ & $\pm \mathrm{SD}(\mu \mathrm{g} / \mathrm{g})$ & $D^{\mathrm{a}}(\%)$ \\
\hline 0.48 & 0.02 & 0.450 & 0.016 & -6.3 & 0.433 & 0.019 & -9.8 \\
\hline
\end{tabular}

\footnotetext{
${ }^{\text {a }}$ Deviation - a difference between a measured value and a certified value, divided by the certified value
} 
Statistical analysis

For statistical computations, the $\mathrm{R}$ language ( $\mathrm{R}$ Development Core Team 2009) was utilized. $R$ is a free software environment for statistical computing and graphics. The capabilities of $\mathrm{R}$ can be extended through packages, which allow specialized statistical techniques, graphical devices, programming interfaces and import/export capabilities to many external data formats.

The results were analysed using the comparison factor (CF), defined as a ratio of a difference between the concentrations of an analyte in lichens $\left(c_{i}\right.$, lichen $)$ and in mosses $\left(c_{i}\right.$, moss $)$, to the arithmetic mean of these concentrations:

$\mathrm{CF}=\frac{2 \cdot\left(c_{i, \text { lichen }}-c_{i, \mathrm{moss}}\right)}{c_{i, \text { lichen }}+c_{i, \text { moss }}}$

For the bioavailable pollutants, the $\mathrm{CF}$ values higher than 0.62 characterize the areas, in which the deposited heavy metals originated from primary emissions to the atmosphere, and not from the secondary enrichment of the atmospheric aerosol with local soil pollutants (Kłos et al. 2010). The limiting value of $\mathrm{CF}$ was determined by the analysis of a data set containing the concentrations of heavy metals accumulated in samples of epiphytic lichens and epigeal mosses from our own measurements and from 257 published measurements in various regions of Europe. In the range $-0.62<\mathrm{CF}<0.62$, which contained $67 \%$ of all results, a statistically significant

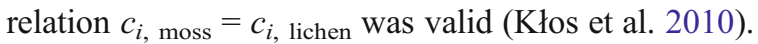

\section{Results and discussion}

The results were interpreted using the statistical parameters of mercury distribution in lichens, mosses and soil. The surface distributions of mercury and of the CF coefficient were also visualized.

Statistical parameters of the distribution of $\mathrm{Hg}$ concentration in the lichen, moss and soil

The distribution of mercury concentration in the lichen, moss and soil samples collected in the forested areas of $\mathrm{BS}, \mathrm{BN}, \mathrm{KK}$ and $\mathrm{J}$ was described using several parameters: maximum and minimum values, upper and lower quartiles, a median and outlying points (McGill et al. 1978). Figure 2 shows the graphical representation of the determined parameters.

The statistical parameters shown in Fig. 2 indicate small dispersion of mercury concentration in the lichen and in the moss from the BS, BN and $\mathrm{J}$ areas. The dispersion in samples from the KK area is slightly higher. Such results indicate a comparable bioavailability of mercury in the considered areas. Much higher dispersion of mercury concentration was found for the soil samples (Fig. 2). This could result from different organic and mineral composition of soil samples and, consequently, from different properties of sorbing complexes (Głuszcz et al. 2008; Che et al. 2003). The authors point to the necessity of proper identification of the genetic levels of sampled soil (Suchara and Sucharova 2002). It should also be noted that soil becomes an increasingly popular matrix used for evaluation of environmental pollution (Suchara and Sucharova 2002; Lado et al. 2008).

The areas were compared in pairs using the MannWhitney $U$ test. Concentrations of mercury in soil samples from the $\mathrm{BS}, \mathrm{BN}, \mathrm{KK}$ and $\mathrm{J}$ areas were found comparable at the significance level $p$ ranging from 0.33 to 0.79 , which indicated a historical deposition of $\mathrm{Hg}$ from remote sources in the whole researched area. In several areas, the concentrations of mercury in lichens were also shown similar: $\mathrm{BS}$ and $\mathrm{BN}(p=$ $0.19)$, BS and $\mathrm{J}(p=0.26)$, and $\mathrm{BN}$ and $\mathrm{J}(p=0.93)$. The test showed the statistically significant differences between $\mathrm{Hg}$ concentrations in mosses collected from different areas $(p<0.05)$. The lack of correlation between the biological material and soil probably reflected the fact that mosses and lichens accumulated mostly the bioavailable forms of mercury.

It is important to compare the pollution data obtained for the considered areas with similar data reported for other areas. The concentrations of mercury in the lichen samples, obtained in this work, do not exceed the concentrations measured in several national parks: from 0.045 to $0.660 \mu \mathrm{g} \mathrm{g}^{-1}$ in Kejimkujik National Park, Nova Scotia, Canada (Rencz et al. 2003) and from 0.07 to $0.29 \mu \mathrm{g} \mathrm{g}^{-1}$ in Yellowstone National Park, USA (Bennett and Wetmore 1999). They are much lower than the concentrations in lichens living near a chemical plant using a mercury technology to manufacture chlorine (Sensen and Richardson 2002). The concentrations of mercury accumulated in the moss matched the range 

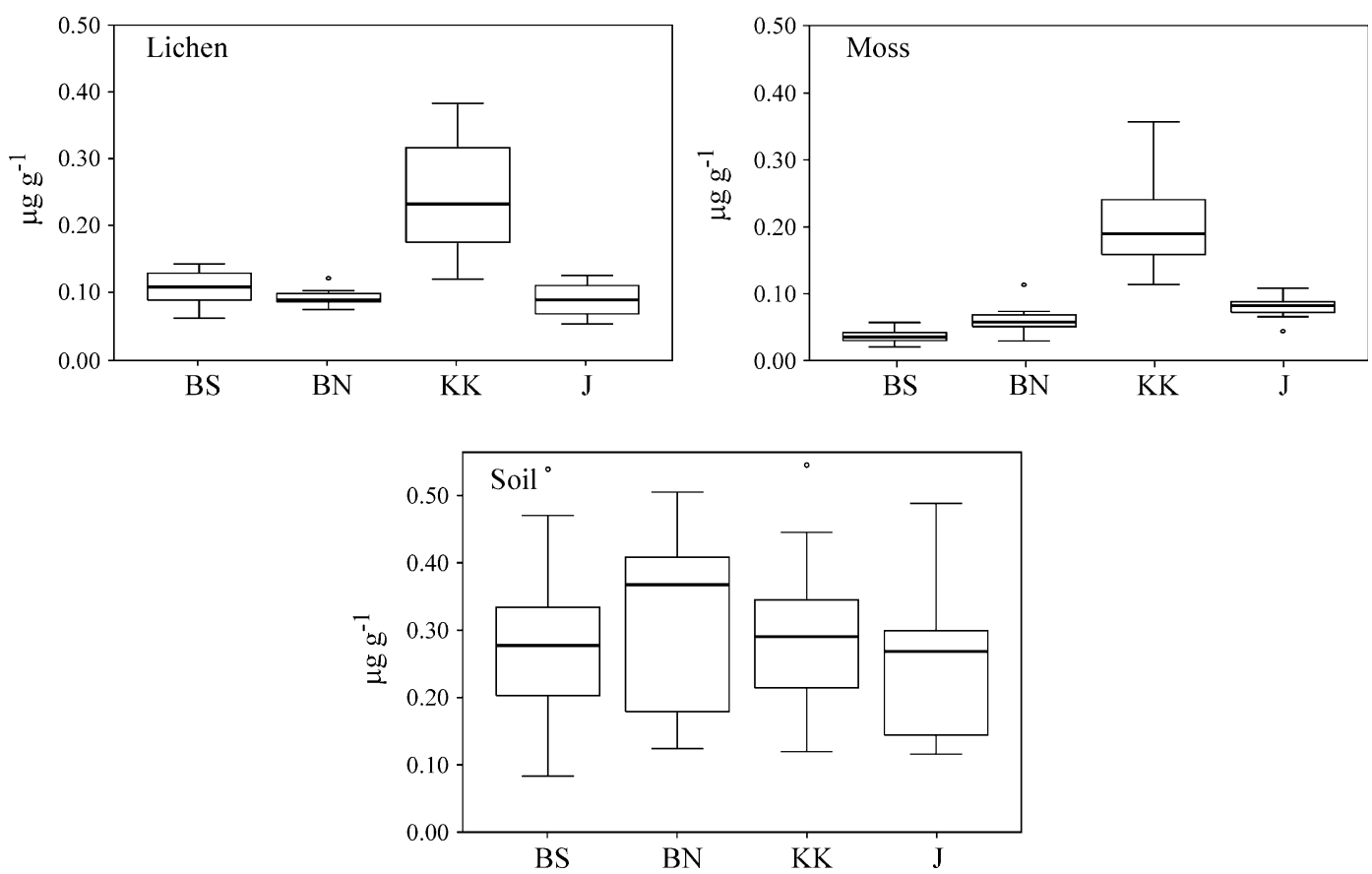

Fig. 2 Statistical parameters describing the distribution of $\mathrm{Hg}$ concentration in the lichen, moss and soil collected in the forested areas of BS, $\mathrm{BN}, \mathrm{KK}$ and $\mathrm{J}$

of 0.012 to $0.14 \mu \mathrm{g} \mathrm{g}^{-1}$, determined in 2005 for other European regions (Harmens et al. 2010a, b). The concentrations of mercury found in the surface soil layer are comparable to the value of $0.633 \mu \mathrm{g} \mathrm{g}$, obtained for the Bohemian Switzerland National Park in Czech Republic (Navrátil et al. 2009). On the other hand, they are several times higher than the concentrations determined in the Holy Cross Mountains, Poland (Migaszewski et al. 2002), and in the Wigierski National Park, Poland (Migaszewski et al. 2005). To sum up, the comparison shows that the mercury contamination of the area monitored in this work does not differ significantly from the contamination in other less-industrialized countries of Europe.

Surface distribution of $\mathrm{Hg}$ concentration in the BS, $\mathrm{BN}, \mathrm{KK}$ and $\mathrm{J}$ regions

Figure 3 shows the maps of the regions considered in this work, which visualize the surface distribution of mercury concentration. Circles of different sizes mark the places which differed in the concentration of mercury determined in the lichen, moss and soil (Fig. 3a-c, respectively). Figure $3 \mathrm{~d}$ shows the places of the primary deposition of mercury, indicated by the CF coefficient (Eq. 1).
The results, presented in Figs. 2 and $3 \mathrm{a}-\mathrm{c}$, indicate a disproportional distribution of mercury over the considered regions: $\mathrm{KK}>\mathrm{BS} \approx \mathrm{BN} \approx \mathrm{J}$, based on the lichen; $\mathrm{KK}>\mathrm{J}>\mathrm{BN}>\mathrm{BS}$, based on the moss; and $\mathrm{KK} \approx \mathrm{BS} \approx \mathrm{BN} \approx \mathrm{J}$, based on the soil, which is consistent with the results of the Mann-Whitney $U$ test. The observation supports a thesis that lichens and mosses cannot replace each other in the biomonitoring studies (Bargagli et al. 2002). The main reason of this limitation is the different influence of soil contaminants on the epiphytic lichens and epigeal mosses (Kłos et al. 2010).

The coefficients CF (Fig. 3d) indicate that the most significant deposition of mercury took place in the BS area, while the concentration of mercury accumulated in lichens and mosses shows that the most polluted area was KK. The contradiction can be explained only if sources of emission, land relief and climate conditions of $\mathrm{KK}$ and $\mathrm{BS}$ are considered simultaneously.

$\mathrm{KK}$ is influenced by surface emission of mercury, mainly from the municipal and housing facilities, which constituted only $9 \%$ of the total emission of mercury in the scale of all Poland, in 2008 (Dębski et al. 2009). It is a valley surrounded by mountains, which rise from 300 to $1,000 \mathrm{~m}$ high. 


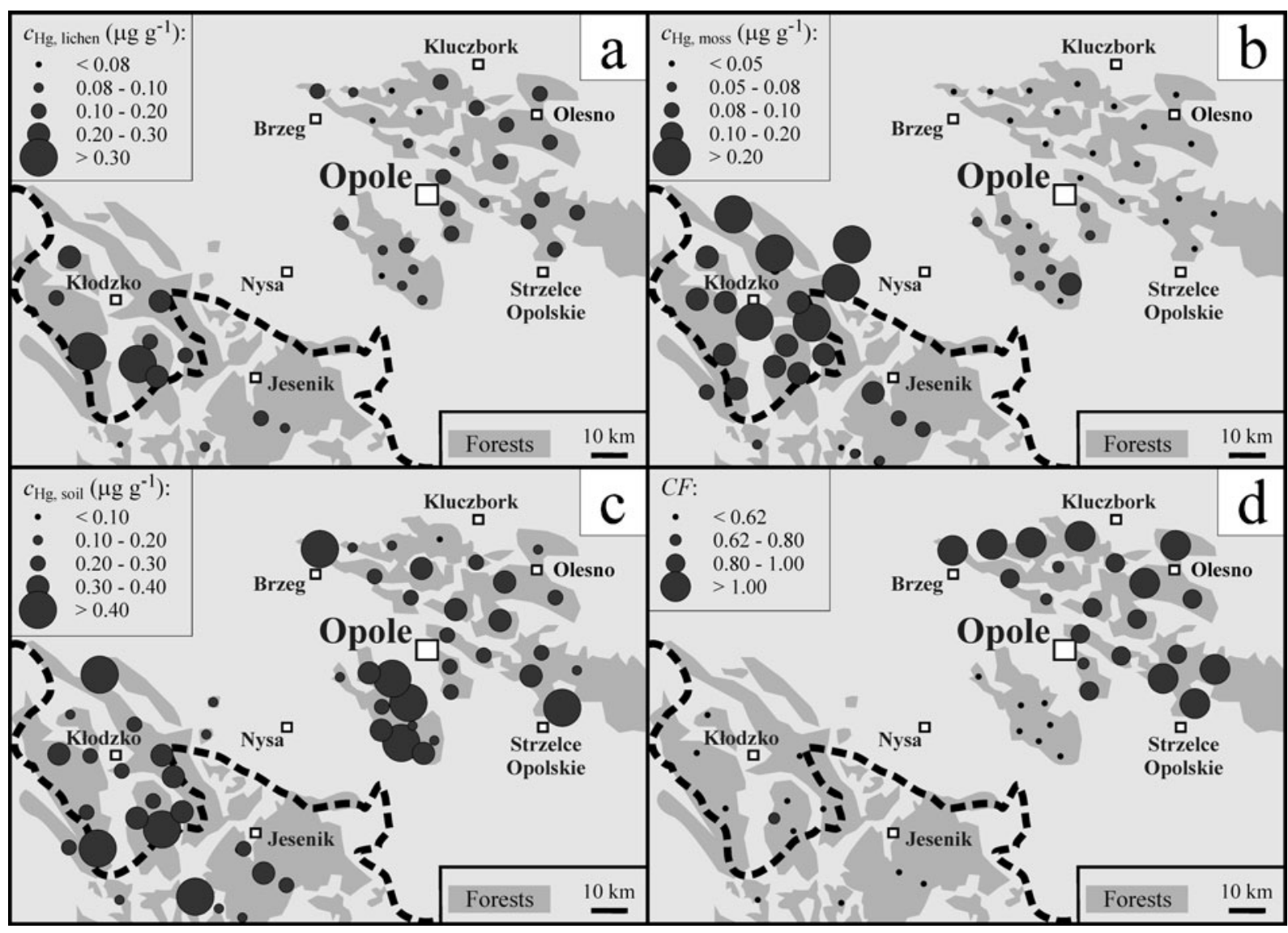

Fig. 3 Surface distribution of mercury concentration in the BS, BN, KK and J regions. a Based on the lichen samples, $\mathbf{b}$ based on the moss samples, $\mathbf{c}$ based on the soil samples and $\mathbf{d}$ characterized with the CF comparison factor for the lichen and the moss samples

The ventilation of the valley is slightly dominated by southern winds and interrupted by long windless periods. For instance, the calms took $26.1 \%$ of the period 1971-2000 (Ecophysiographic Development for Lower Silesia 2005). Lower inversions of temperature in the valley reduce the air exchange and promote the formation of smog. Under such conditions, the pollutants, including the uplifted dust, are suspended in the air for a long time and have more chances to contact the surfaces of lichens and mosses.

Pollutants which deposit in the area of BS originate mostly from urban and industrial sources. In 2008, the energy and industry sectors contributed almost $91 \%$ of the total mercury emission in Poland (Dębski et al. 2009). The third most important source of mercury emission was cement production (Głodek and Pacyna 2009). Several cement works are located directly in and close to Opole. The BS and BN are both flat areas covered by spruce and pine forests. Dominating north-east winds make BS more influenced than BN by urban and industrial emissions from Opole. Most of the potential sources of mercury emissions are located along the Strzelce Opolskie-Opole-Brzeg line. They include the aforementioned cement works in Strzelce Opolskie, Opole and Górażdże (not shown on the maps but located between the two latter places); local thermal power stations fired with hard coal; and a professional coal-fired electric power station near Opole. Attention has to be paid to emissions inflowing from the nearby Upper Silesian Industrial Region (Górnośląski Okręg Przemysłowy, GOP), located east of the BS region. In 2009, the concentrations of elemental mercury in air in the GOP region were 1.7-1.8 $\mathrm{ng} \mathrm{m}^{3}$ (Ilyin et al. 2011). Earlier studies, based on the CF factor, revealed the deposition of $\mathrm{Zn}$ and $\mathrm{Cd}$ in BS (Kłos et al. 2010).

The results of this work prove that the climate conditions - mostly humidity, as well as type and 
frequency of atmospheric precipitation - significantly influence the accumulation of pollutants in lichens and mosses, and should be routinely taken into account in the comparative biomonitoring studies based on these matrices (Harmens et al. 2010a, b). The influence of climate conditions on sorption of heavy metals by lichens has been indicated in other works (Williamson et al. 2004).

\section{Conclusions}

The biomonitoring studies based on lichens and mosses provide significant information on the pollution of ecosystems, and on the transport vectors and bioavailability of pollutants. The adequate interpretation of collected data is not easy, because the interaction of biosorbents with the environment is multifactorial. Consequently, the interpretation has to include many abiotic factors, such as climate conditions, that influence the sorption of pollutants by the biological materials.

The presented results show that the concentrations of mercury accumulated in the lichen, moss and soil samples collected in the Praded and Glacensis Euroregions are statistically similar to the concentrations determined for other areas located far from significant sources of mercury. However, the individual matrices indicated different surface distributions of mercury in the considered regions (Fig. 3).

This work introduced a new way of analysing the results of biomonitoring, based on the $\mathrm{CF}$ defined as a ratio of a difference between the concentrations of an analyte in lichens and in mosses, to the arithmetic mean of these concentrations. The CF values higher than 0.62 hypothetically indicate that a deposited bioavailable analyte had been introduced into the atmosphere by primary emission, and not by the secondary enrichment of the atmospheric aerosol with the local soil pollutants. The hypothesis requires further confirmation based on data from various geographical regions.

The CF values determined for the areas considered in this work indicate that the primary emission of mercury influenced mostly the area of Bory Stobrawskie. This coincides well with the location of potential sources of urban and industrial emission of mercury, as well as with the local climate conditions. The background level of mercury pollution, caused by remote sources, was difficult to estimate from the presented data.
Open Access This article is distributed under the terms of the Creative Commons Attribution Noncommercial License which permits any noncommercial use, distribution, and reproduction in any medium, provided the original author(s) and source are credited.

\section{References}

Bargagli, R., Monaci, F., Borghini, F., Bravi, F., \& Agnorelli, C. (2002). Mosses and lichens as biomonitors of trace metals. A comparison study on Hypnum cupressiforme and Parmelia caperata in a former mining district in Italy. Environmental Pollution, 116, 279-287.

Becnel, J., Falgeust, C., Cavalier, T., Gauthreaux, K., Landry, F., Blanchard, M., et al. (2004). Correlation of mercury concentrations in tree core and lichen samples in southeastern Louisiana. Microchemical Journal, 78, 205-210.

Bennett, J. P., \& Wetmore, C. M. (1997). Chemical element concentrations in four lichens on a transect entering Voyageurs National Park. Environmental and Experimental Botany, 37, 173-185.

Bennett, J. P., \& Wetmore, C. M. (1999). Geothermal elements in lichens of Yellowstone National Park, USA. Environmental and Experimental Botany, 42, 191-200.

Boszke, L., Kowalski, A., Astel, A., Barański, A., Gworek, B., \& Siepak, J. (2008). Mercury mobility and bioavailability in soil from contaminated area. Environmental Geology, $55,1075-1087$.

Carignan, J., \& Sonke, J. (2010). The effect of atmospheric mercury depletion events on the net deposition flux around Hudson Bay, Canada. Atmospheric Environment, 44, 4372-4379.

Che, D., Meagher, R. B., Heaton, A. C. P., Lima, A., Rugh, C. L., \& Merkle, S. A. (2003). Expression of mercuric ion reductase in Eastern cottonwood (Populus deltoides) confers mercuric ion reduction and resistance. Plant Biotechnology Journal, 1(4), 311-319.

Commission of the European Communities. (2005). Communication from the Commission to the Council and the European Parliament. Community strategy concerning mercury, Brussels, 28.01. 2005. http://eur-lex.europa.eu/ LexUriServ/site/en/com/2005/com2005_0020en01.pdf. Accessed 06 December 2010.

Dang, F., \& Wang, W.-X. (2010). Subcellular controls of mercury trophic transfer to a marine fish. Aquatic Toxicology, 99, 500-506.

Dębski, B., Olendrzyński, K., Cieślińska, J., Kargulewicz, I., Skośkiewicz, J., Olecka, A., et al. (2009). Inwentaryzacja emisji do powietrza $\mathrm{SO}_{2}, \mathrm{NO}_{x}, \mathrm{CO}, \mathrm{NH}_{3}$, pylów, metali ciężkich, NMLZO i TZO w Polsce za rok 2008 (Inventory of $\mathrm{SO}_{2}, \mathrm{NO}_{X}, \mathrm{CO}, \mathrm{NH}_{3}$, particles, heavy metals, NMVOC, POP emission to air in Poland for 2008). Warsaw: KASHUE-KOBiZE and Instytut Ochrony Środowiska w Warszawie.

Ecophysiographic Development for Lower Silesia. (2005). Wrocław, Poland: Wojewódzkie Biuro Urbanistyczne we Wrocławiu.

EMEP (2010). Pollution of the EMEP region. http://www. msceast.org/hms/hg_emis.pdf. Accessed 25 August 2011. 
Ettler, V., Rohovec, J., Navrátil, T., \& Mihaljevič, M. (2007). Mercury distribution in soil profiles polluted by lead smelting. Bulletin of Environmental Contamination and Toxicology, 78, 13-17.

Fraenzle, S., \& Markert, B. (2007). Metals in biomass: From the biological system of elements to reasons of fractionation and element use. Environmental Science and Pollution Research, 6, 404-413.

Głodek, A., \& Pacyna, J. M. (2009). Mercury emission from coal-fired power plants in Poland. Atmospheric Environment, 43(35), 5668-5673.

Głuszcz, P., Zakrzewska, K., Wagner-Doebler, I., \& Ledakowicz, S. (2008). Bioreduction of ionic mercury from wastewater in a fixed-bed bioreactor with activated carbon. Chemical Papers, 62(3), 232-238.

Harmens, H., Mills, G., Hayes, F., Jones, L., Norris, D., \& Cooper, D. (2009) ICP Vegetation annual report 2008/2009. http:// icpvegetation.ceh.ac.uk. Accessed 10 December 2010.

Harmens, H., Norris, D. A., Steinnes, E., Kubin, E., Piispanen, J., Alber, R., et al. (2010a). Mosses as biomonitors of atmospheric heavy metal deposition: Spatial patterns and temporal trends in Europe. Environmental Pollution, 158, 3144-3156.

Harmens, H., Mills, G., Hayes, F., \& Norris, D. (2010b). ICP Vegetation annual report 2009/2010. http://icpvegetation. ceh.ac.uk. Accessed 02 October 2011.

Ilyin, I., Rozovskaya, O., Travnikov, O., Varygina, M., Aas, W., \& Uggerud H. T. (2011). Heavy metals: Transboundary pollution of the environment, EMEP Status Report 2/2011, Norwegian Institute for Air Research, Kjeller, Norway and Meteorological Synthesizing Centre-East, Moscow, Russia.

Kehrig, H. A., Seixas, T. G., Baęta, A. P., Malm, O., \& Moreira, I. (2010). Inorganic and methylmercury: Do they transfer along a tropical coastal food web? Marine Pollution Bulletin, 60, 2350-2356.

Kłos, A., Rajfur, M., Wacławek, M., Wacławek, W., Wünschmann, S., \& Markert, B. (2010). Quantitative relations between different concentrations of micro- and macroelements in mosses and lichens: The region of Opole (Poland) as an environmental interface in between Eastern and Western Europe. International Journal of Environment and Health, 4(2/3), 98-119.

Lado, L. R., Hengl, T., \& Reuter, H. I. (2008). Heavy metals in European soils: A geostatistical analysis of the FOREGS Geochemical database. Geoderma, 148, 189-199.

Loppi, S., Paoli, L., \& Gaggi, C. (2006). Diversity of epiphytic lichens and $\mathrm{Hg}$ contents of Xanthoria parietina Thalli as monitors of geothermal air pollution in the Mt. Amiata Area (Central Italy). Journal of Atmospheric Chemistry, 53, 93-105.

Markert, B. (2007). Definitions and principles for bioindication and biomonitoring of trace metals in the environment. Journal of Trace Elements in Medicine and Biology, 21 (S1), 77-82.

Markert, B., Breure, A., \& Zechmeister, H. (2003). Bioindicators \& biomonitors: Principles, concepts and applications. Amsterdam: Elsevier.

Markert, B., Wuenschmann, S., Fraenzle, S., Wappelhorst, O., Weckert, V., Breulmann, G., et al. (2008). On the road from environmental biomonitoring to human health aspects: Monitoring atmospheric heavy metal deposition by epiphytic/epigeic plants: Present status and future needs. International Journal of Environment and Pollution, 32, 486-498.

McGill, R., Tukey, J. W., \& Larsen, W. A. (1978). Variations of box plots. American Statistical, 32(1), 12-16.

Migaszewski, Z. M., Gałuszka, A., \& Pasławski, P. (2002). Polynuclear aromatic hydrocarbons, phenols, and trace metals in selected soil profiles and plant bioindicators in the Holy Cross Mountains, South-Central Poland. Environment International, 28, 303-313.

Migaszewski, Z. M., Gałuszka, A., \& Pasławski, P. (2005). The use of the barbell cluster ANOVA design for the assessment of environmental pollution: A case study, Wigierski National Park, NE Poland. Environmental Pollution, 133, 213-223.

Navrátil, T., Hojdová, M., Rohovec, J., Penížek, V., \& Vařilova, Z. (2009). Effect of fire on pools of mercury in forest soil, Central Europe. Bulletin of Environmental Contamination and Toxicology, 83, 269-274.

Overarching Framework UNEP Global Mercury Partnership. (2009). United Nations Environment Programme. http:/hqweb.unep.org/hazardoussubstances/Mercury/ GlobalMercuryPartnership/PartnershipOverarchingFrame work/tabid/4783/language/en-US/Default.aspx. Accessed 06 December 2010.

Pacyna, E. G., Pacyna, J. M., Fudała, J., Strzelecka-Jastrząb, E., Hławiczka, S., \& Panasiuk, D. (2006). Mercury emissions to the atmosphere from anthropogenic sources in Europe in 2000 and their scenarios until 2020. Science of the Total Environment, 370, 147-156.

R Development Core Team. (2009). R: A language and environment for statistical computing. R Foundation for Statistical Computing. Vienna, Austria. ISBN 3-90005107-0, URL http://www.R-project.org/.

Rencz, A. N., O’Driscoll, N. J., Hall, G. E. M., Peron, T., Telmer, K., \& Burgess, N. M. (2003). Spatial variation and correlations of mercury levels in the terrestrial and aquatic components of a wetland dominated ecosystem: Kejimkujik Park, Nova Scotia, Canada. Water, Air, and Soil Pollution, 143, 271-288.

Ribeiro Guevara, S., Bubach, D., \& Arribére, M. (2004). Mercury in lichens of Nahuel Huapi National Park, Patagonia, Argentina. Journal of Radioanalytical and Nuclear Chemistry, 261(3), 679-687.

Sensen, M., \& Richardson, D. H. S. (2002). Mercury levels in lichens from different host trees around a chloralkali plant in New Brunswick, Canada. Science of the Total Environment, 293, 31-45.

Smodiš, B., Pignata, M. L., Saiki, M., Cortés, E., Bangfa, N., Markert, B., et al. (2004). Validation and application of plants as biomonitors of trace element atmospheric pollution-A co-ordinated effort in 14 countries. Journal of Atmospheric Chemistry, 49, 3-13.

Steinnes, E., Berg, T., \& Sjøbakk, T. E. (2003). Temporal and spatial trends in $\mathrm{Hg}$ deposition monitored by moss analysis. The Science of the Total Environment, 304, 215-219.

Suchara, I., \& Sucharova, J. (2002). Distribution of sulphur and heavy metals in forest floor humus of the Czech Republic. Water, Air, and Soil Pollution, 136, 289-316. 
Suchara, I., \& Sucharova, J. (2008). Mercury distribution around the Spolana chlor-alkali plant (central Bohemia, Czech Republic) after a catastrophic flood, as revealed by bioindicators. Environmental Pollution, 151, 352-361.

Suchara, I., Maňkovská, B., Sucharová, J., Florek, M., Godzik, B., Rabnecz, G., et al. (2007). Mapping of main sources of pollutants and their transport in the Visegrad space. Part II: Fifty three elements. Zvolen: KLEMO spol. s r.o., (Ltd.).

Travnikov, O. (2005). Contribution of the intercontinental atmospheric transport to mercury pollution in the Northern Hemisphere. Atmospheric Environment, 39, 7541-7548.
Williamson, B. J., Mikhailova, I., Purvis, O. W., \& Udachin, V. (2004). SEM-EDX analysis in the source apportionment of particulate matter on Hypogymnia physodes lichen transplants around the $\mathrm{Cu}$ smelter and former mining town of Karabash, South Urals, Russia. Science of the Total Environment, 322, 139-154.

Wolterbeek, B. (2003). Biomonitoring of trace element air pollution: Principles, possibilities and perspectives. In Proc. of the International Workshop-BioMAP II, 28 August-3 September 2000, (pp. 87-104), Vienna: IAEA. 